\title{
Calcitonin Gene-Related Peptide Reduces Taste-Evoked ATP Secretion from Mouse Taste Buds
}

\author{
Anthony Y. Huang ${ }^{1,2}$ and Sandy Y. Wu ${ }^{1}$ \\ ${ }^{1}$ Department of Anatomy and ${ }^{2}$ Center for Integrated Research in Cognitive and Neural Science, Southern Illinois University School of Medicine, \\ Carbondale, Illinois 62901
}

Immunoelectron microscopy revealed that peripheral afferent nerve fibers innervating taste buds contain calcitonin gene-related peptide (CGRP), which may be as an efferent transmitter released from peripheral axon terminals. In this report, we determined the targets of CGRP within taste buds and studied what effect CGRP exerts on taste bud function. We isolated mouse taste buds and taste cells, conducted functional imaging using Fura-2, and used cellular biosensors to monitor taste-evoked transmitter release. The findings showed that a subset of Presynaptic (Type III) taste cells (53\%) responded to $0.1 \mu \mathrm{M}$ CGRP with an increase in intracellular Ca ${ }^{2+}$. In contrast, Receptor (Type II) taste cells rarely (4\%) responded to $0.1 \mu \mathrm{M}$ CGRP. Using pharmacological tools, the actions of CGRP were probed and elucidated by the CGRP receptor antagonist $\mathrm{CGRP}_{8-37}$. We demonstrated that this effect of CGRP was dependent on phospholipase $\mathrm{C}$ activation and was prevented by the inhibitor U73122. Moreover, applying CGRP caused taste buds to secrete serotonin (5-HT), a Presynaptic (Type III) cell transmitter, but not ATP, a Receptor (Type II) cell transmitter. Further, our previous studies showed that 5-HT released from Presynaptic (Type III) cells provides negative paracrine feedback onto Receptor (Type II) cells by activating $5-\mathrm{HT}_{1 \mathrm{~A}}$ receptors, and reducing ATP secretion. Our data showed that CGRP-evoked 5-HT release reduced taste-evoked ATP secretion. The findings are consistent with a role for CGRP as an inhibitory transmitter that shapes peripheral taste signals via serotonergic signaling during processing gustatory information in taste buds.

Key words: ATP; biosensors; $\mathrm{Ca}^{2+}$ imaging; CGRP; serotonin; taste

\section{Significance Statement}

The taste sensation is initiated with a highly complex set of interactions between a variety of cells located within the taste buds before signal propagation to the brain. Afferent signals from the oral cavity are carried to the brain in chemosensory fibers that contribute to chemesthesis, the general chemical sensitivity of the mucus membranes in the oronasal cavities and being perceived as pungency, irritation, or heat. This is a study of a fundamental question in neurobiology: how are signals processed in sensory end organs, taste buds? More specifically, taste-modifying interactions, via transmitters, between gustatory and chemosensory afferents inside taste buds will help explain how a coherent output is formed before being transmitted to the brain.

\section{Introduction}

Taste cells, classified into Types I, II, and III originally based on their histology and ultrastructure, are more recently distinguished by their expression patterns of key proteins involved in taste transduction (Chaudhari and Roper, 2010). Among these

Received Jan. 8, 2015; revised Aug. 7, 2015; accepted Aug. 7, 2015.

Author contributions: A.Y.H. and S.Y.W. designed research; A.Y.H. and S.Y.W. performed research; A.Y.H. and S.Y.W. analyzed data; A.Y.H. wrote the paper.

This work was supported by SIUSOM Faculty Research Seed Grant to A.Y.H. We thank Drs. K. Bergs and S. Roper for the generous gifts of $\mathrm{CH} 0 / 5-\mathrm{HT}_{2 \mathrm{C}}$ and $\mathrm{CH} 0 / \mathrm{P} 2 \mathrm{X}_{2} / \mathrm{P} 2 \mathrm{X} 3$ cells, respectively; and Dr. I. Dickerson for the generous gift of the RCP antibody.

The authors declare no competing financial interests.

Correspondence should be addressed to Dr. Anthony Y. Huang, Department of Anatomy, Southern Illinois University School of Medicine, 1135 Lincoln Drive, Carbondale, IL 62901. E-mail: ahuang@siumed.edu.

DOI:10.1523/JNEUROSCI.0100-15.2015

Copyright $\odot 2015$ the authors $\quad 0270-6474 / 15 / 3512714-11 \$ 15.00 / 0$ morphotypes, Type II taste cells have been called Receptor taste cells because they express G-protein-coupled receptors (GPCRs) for sweet, umami, or bitter. Upon taste stimulation, Receptor (Type II) cells secrete ATP via membrane channels (Huang et al., 2007; Romanov et al., 2007; Taruno et al., 2013). Type III taste cells, identified as only taste cells forming ultrastructural specializations associated with synapses, have also been named Presynaptic taste cells. Responding directly to acid (sour) taste stimuli (Huang et al., 2006; Huang et al., 2008b; Chang et al., 2010), and to high concentrations of $\mathrm{KCl}$ (Huang et al., 2007; Oka et al., 2013), Presynaptic (Type III) cells release serotonin (5-HT), norepinephrine, and GABA into the interstitial space of taste buds (Huang et al., 2007; Huang et al., 2008a, 2011a).

Taste requires initial compilation of cell-cell interactions before a coherent output is transmitted to the brain via pri- 
A
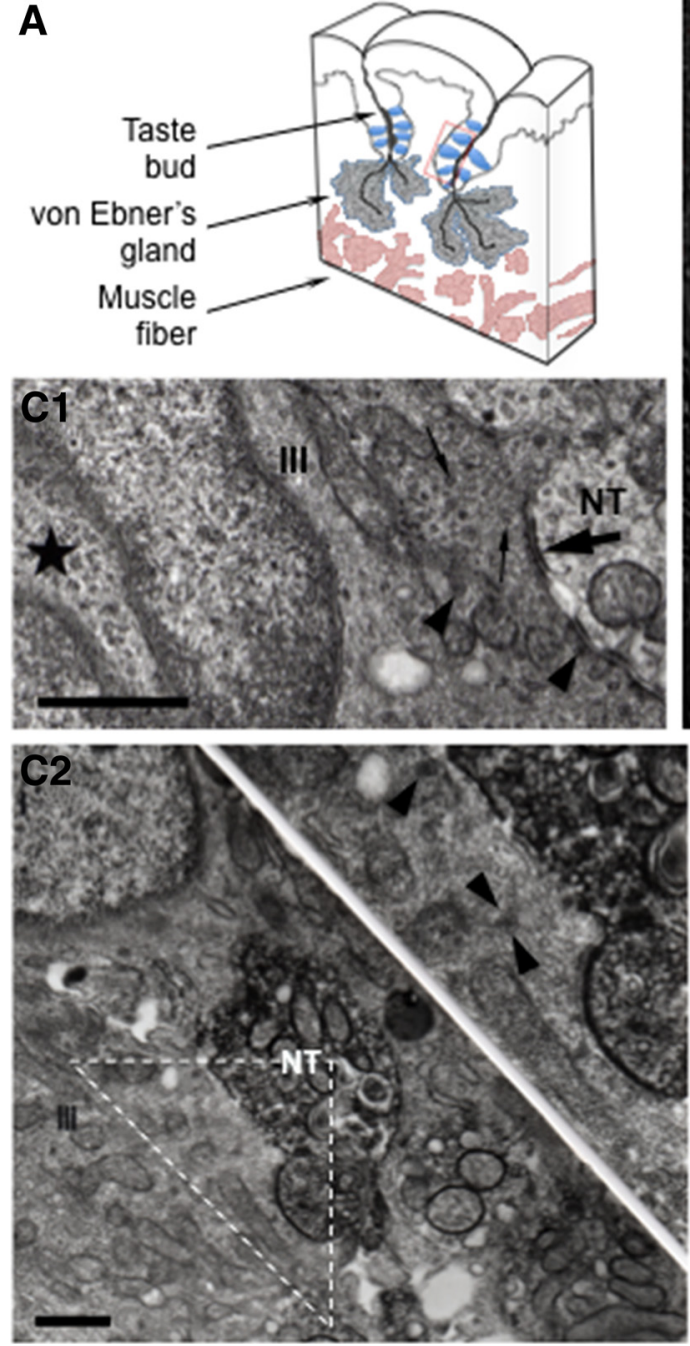
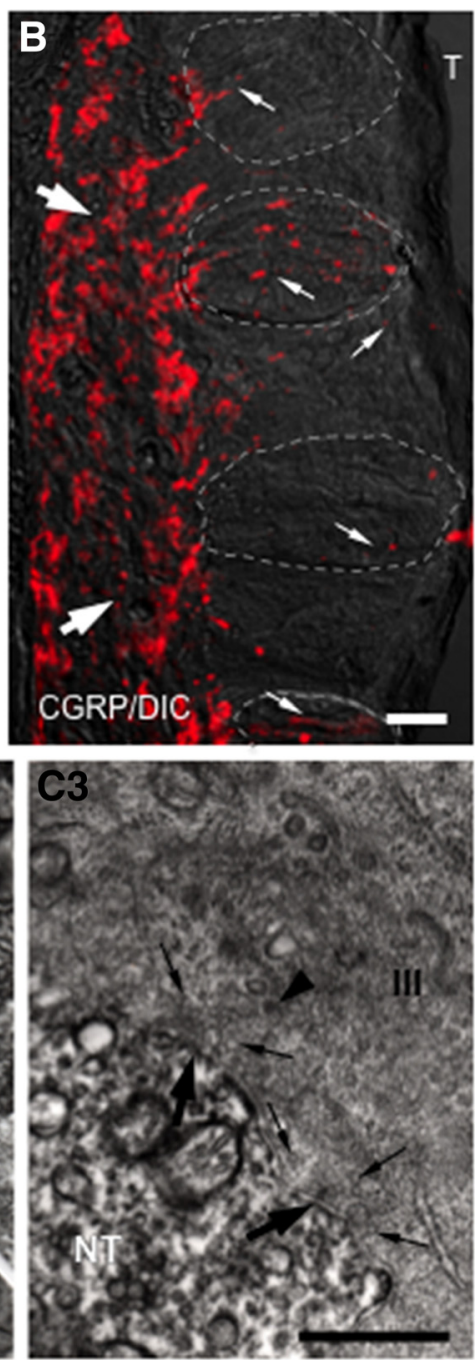

Figure 1. CGRP immunohistochemistry in mouse vallate papillae. $A$, Schematic drawing of a lingual slice containing the vallate papilla. Red box represents approximate position of the taste buds in $\boldsymbol{B}$. $\boldsymbol{B}$, A Nomarski optics image was merged with an immunofluorescent confocal micrograph for this micrograph (CGRP/DIC). Numerous CGRP-immunoreactive nerve fibers forming a dense network (large arrows) are seen in the connective tissue core of the papilla. Fine CGRP-immunoreactive varicose nerve fibers (small arrows) running within, or in close association with, taste buds (areas of dashed lines) and coursing through the entire thickness of the epithelium, are clearly seen. The optical thickness (z-stack) of the confocal image is $13 \mu \mathrm{m}$. T, Trench. Scale bar, $50 \mu \mathrm{m}$. $\boldsymbol{C}$, Ultrastructure of synapses in taste buds. C1, Synapses between a Presynaptic (Type III) cells and non-CGRP-immunoreactive nerve terminals (NT). The Presynaptic (Type III) cell (III) has an ovoid nucleus with deep invagination ( $\star$ ) as well as possesses many dense-cored vesicles (arrowheads), accumulation of clear vesicles (small arrows), and mitochondria at areas of membrane specialization (large arrow). C2, C3, Based on the intense electron-dense precipitate distributed diffusely throughout the cytoplasm of nerve processes, electron micrographs represent CGRP-immunoreactive nerve terminals in apparent contact with Presynaptic (Type III) cells. Inset, Higher magnification of the triangle in (2. The accumulation of clear (small arrows) and dense-cored vesicles (arrowhead) at areas of membrane specialization (large arrows) in (3 is seen. Scale bar, $500 \mathrm{~nm}$.

Calcitonin gene-related peptide (CGRP), a 37 amino acid vasodilatory neuropeptide produced in the chemosensory neurons (Silverman and Kruger, 1989, 1990; Ishida et al., 2002; Huang et al., 2003; Hayakawa et al., 2010, 2014; Ceruti et al., 2011), that contributes to chemethesis, the general chemical sensitivity mucus membranes in the oronasal cavities and being perceived as pungency, irritation, or heat (Green, 2012; Roper, 2014), transmits vascular nociception. Certain of these sensations are thought to be mediated by the transient receptor potential vaniloid 1 (TRPV1) (Ishida et al., 2002; Vandewauw et al., 2013). Intriguingly, despite the profusion of work identifying mechanisms of chemesthesis, little information has been generated regarding irritant-taste interactions.

In addition to evoking nociceptive responses to chemical irritants as part of a common chemical sense, the extensive innervation of those areas where taste buds can be expected may contribute to specific chemical sensitivities relating to the taste. A number of findings have subsequently supported that notion. For instance, electrophysiology revealed that capsaicin was able to modulate taste nerve responses to other taste compounds (Wang et al., 1995). This modulation was interpreted as being produced indirectly, via stimulation of peripheral sensory nerve terminals that have ability to release stored transmitters (e.g., CGRP) onto taste cells, by the sensory-efferent functions of the capsaicin-sensitive sensory neurons (Holzer, 1988; Maggi and Meli, 1988; Wang et al., 1995; Simon et al., 2003). Indeed, immunohistochemistry revealed that CGRP and TRPV1 coexist in the sensory neurons innervating the circumvallate papillae (Ishida et al., 2002). Conceivably, these studies point to a role for CGRP as an efferent transmitter in the peripheral taste organs, although the detailed actions of CGRP in the taste buds remain to be tested.

To test this assumption, we investimary gustatory afferent fibers (Finger et al., 2005; Huang et al., 2007; Huang et al., 2009; Herness and Zhao, 2009; Jaber et al., 2014). Several transmitters and signaling molecules have been implicated in these interactions, including 5-HT (Kaya et al., 2004; Huang et al., 2005; Huang et al., 2009; Jaber et al., 2014), ATP (Finger et al., 2005; Huang et al., 2007; Murata et al., 2010), norepinephrine (Dvoryanchikov et al., 2007; Huang et al., 2008a), and GABA (Cao et al., 2009; Dvoryanchikov et al., 2011; Huang et al., 2012). Recent studies reported that ATP is a crucial transmitter to excite gustatory sensory afferent fibers (Finger et al., 2005; Huang et al., 2011b; Vandenbeuch et al., 2015). Furthermore, 5-HT mediates an inhibitory feedback onto Receptor (Type II) cells during taste excitation (Huang et al., 2009). gated whether CGRP affects taste responses. By measuring released ATP using $\mathrm{Ca}^{2+}$ imaging with cellular biosensors, we examined the peptidergic modulation on taste-evoked ATP secretion from mouse taste buds. Our findings unambiguously show that CGRP can shape the peripheral taste signals before their transmission across gustatory fibers.

\section{Materials and Methods}

Animals and ethical approval. We used adult male C57BL/6J mice of either sex obtained from The Jackson Laboratory (http://jaxmice.jax.org/ strain/013636.html) in this study. Mice were killed by cervical dislocation under deep $\mathrm{CO}_{2}(100 \%)$ anesthesia. Briefly, $\mathrm{CO}_{2}$ ensures that mice are unconscious, whereas dislocation ensures quick death. Tongues were 
then removed for the further dissection. All procedures, conducted following the guideline of the National Institute of Health (Office of Animal Care and Use) as well as approved by the Southern Illinois University Animal Care and Use Committee (Animal Welfare Assurance \#A-3078-01), minimize distress.

Isolated taste buds and/or taste cells. Details of how taste buds and cells were isolated were described previously (Huang et al., 2005; Huang et al., 2011a, 2012). Briefly, we injected an enzyme mixture containing $1 \mathrm{mg} / \mathrm{ml}$ collagenase A (Roche), $2.5 \mathrm{mg} / \mathrm{ml}$ dispase II (Roche), and 1 $\mathrm{mg} / \mathrm{ml}$ trypsin inhibitor (Sigma) beneath the epithelium surrounding circumvallate papillae and removed the lingual epithelium. Isolated taste buds were collected in glass micropipettes and transferred to a recording chamber (Warner Instruments) with a glass coverslip base. To isolate single taste cells, individual taste buds were triturated in the recording chamber using a glass micropipette. Taste cells were loaded with $5 \mu \mathrm{M}$ Fura-2 AM (Invitrogen) following their isolation (Huang et al., 2007). During the experiments, taste buds and taste cells were continuously perfused with Tyrode's solution. For the experiments to detect 5-HT release, whole taste buds were preincubated with the 5-HT precursor, 5-hydroxytryptophan $(500 \mu \mathrm{M})$ (Sigma), for $30-45 \mathrm{~min}$ before the start of the experiment to maximize 5-HT loading of taste cells, as reported by Huang et al. (2005).

Biosensor cells. 5-HT biosensors consisted of Chinese hamster ovary ( $\mathrm{CHO}$ ) cells stably expressing 5- $\mathrm{HT}_{2 \mathrm{C}}$ receptors (Berg et al., 1994; Huang et al., 2005). We also used $\mathrm{CHO}$ cells expressing $\mathrm{P} 2 \mathrm{X} 2 / \mathrm{P} 2 \mathrm{X} 3$ receptors (hereafter called ATP biosensors) (Huang et al., 2007). Biosensors were prepared and loaded with 5 $\mu \mathrm{M}$ Fura-2 AM as described previously (Huang et al., 2005, 2007; Huang et al., 2009, 2011a, 2012). An aliquot of fura-2-loaded biosensor cells (5-HT or ATP) was transferred to the recording chamber containing isolated taste buds and/or isolated taste cells. Immediately after 5-HT or ATP biosensors had settled to the bottom of the chamber, they were probed with a single application of 5-HT ( $3 \mathrm{nM})$ or ATP $(0.3-1 \mu \mathrm{M})$. Highly sensitive biosensors were drawn onto a fire-polished glass micropipette to test transmitter release from taste buds (see Fig. 6A).

Biosensor cells alone neither responded to bath-applied $\mathrm{KCl}$ (50 mm) nor to the taste stimuli used in the study (Huang et al., 2005, 2007). Last, we verified that none of the products used in this study affects the sensitivities of 5-HT or ATP biosensors, including CGRP, CGRP ${ }_{8-37}$ (CGRP receptor antagonist), and WAY100635 (5- $\mathrm{HT}_{1 \mathrm{~A}}$ receptor antagonist).

$\mathrm{Ca}^{2+}$ imaging. $\mathrm{Ca}^{2+}$ imaging was performed as described previously (Huang et al., 2005, 2007; Huang et al., 2009, 2011a, 2012). Briefly, conventional $\mathrm{Ca}^{2+}$ imaging was performed using Indec Workbench version 6 software (INDEC Biosystem). Fura-2-loaded cells were excited at 340 and $380 \mathrm{~nm}$, and emission images were collected at $\geq 510 \mathrm{~nm}$. The ratio of F340/F380 was converted to approximate $\left[\mathrm{Ca}^{2+}\right]_{i}$ as described by Grynkiewicz et al. (1985). The fluorescence ratios of free and $\mathrm{Ca}^{2+}$ bound fura- 2 at $340 \mathrm{~nm}$ and the fluorescence ratios of free and $\mathrm{Ca}^{2+}$. bound fura-2 at $380 \mathrm{~nm}$ were determined using a Fura-2 Calcium Imaging Calibration Kit (Invitrogen) (e.g., Huang et al., 2011a). The average baseline (resting) $\mathrm{Ca}^{2+}$ of taste cells in these experiments was $156 \pm 43 \mathrm{~nm}(N=22$ cells $)$, in good correspondence with values reported previously (Huang et al., 2011a).
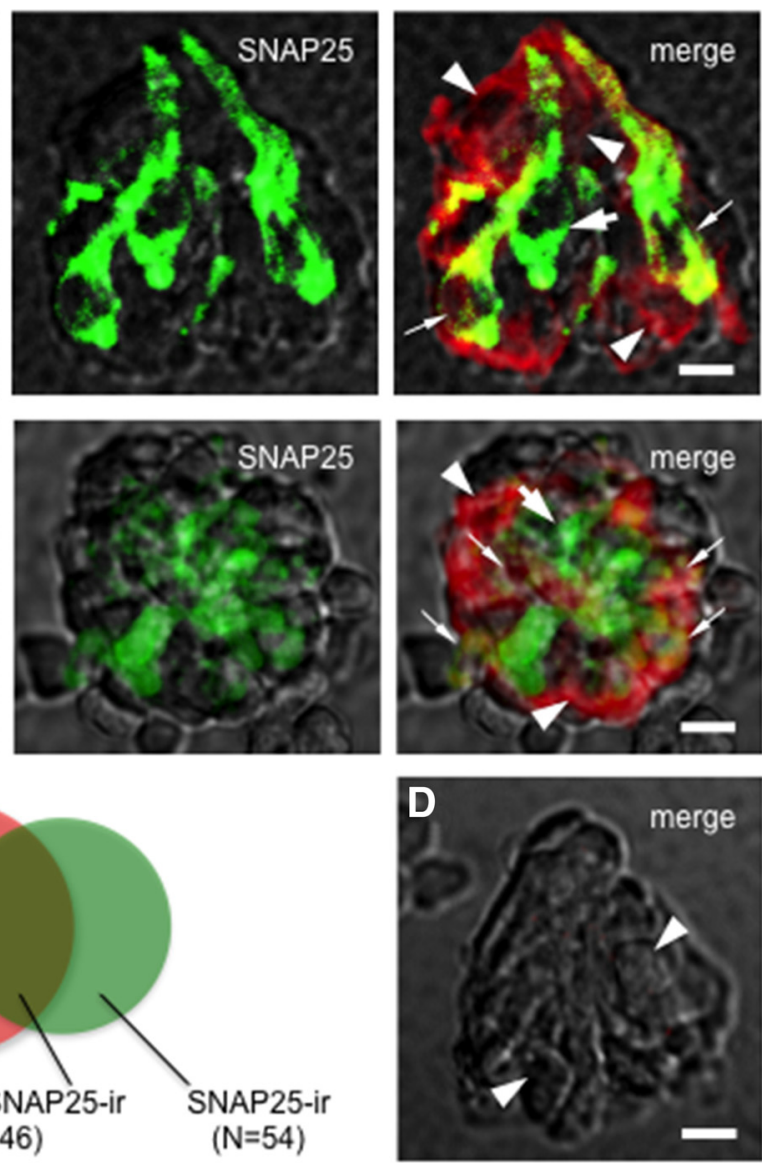

Figure 2. A subset of Presynaptic (Type III) taste cells express RCP. Double immunostaining of isolated and fixed taste buds. orescent confocal micrographs for these micrographs. RCP-immunoreactive (red) taste cells (arrowheads) and SNAP25and $21 \mu \mathrm{m}$ for $A$ and $B$ respectively. Scale bar, $25 \mu \mathrm{m}$. V Venn diagrams representing the relative proportion of taste bud of the both primary antibodies. Note the absence of immunostaining in cells normally rich with RCP and/or SNAP25 immunoreactivity (arrowheads). Compare with Figure $2 \boldsymbol{A}, \boldsymbol{B}$. Scale bar, $25 \mu \mathrm{m}$.

Our criteria for accepting $\mathrm{Ca}^{2+}$ responses for analysis were described fully in our previous publications (Huang et al., 2009, 2011a, 2012). In brief, responses were quantified as peak minus baseline $\left[\mathrm{Ca}^{2+}\right]$ (i.e., $\left.\Delta\left[\mathrm{Ca}^{2+}\right]\right)$. We accepted $\mathrm{Ca}^{2+}$ responses only if they could be elicited repetitively in the same cell by the same stimulus, and evoked responses were at least $2 \times$ baseline $\left[\mathrm{Ca}^{2+}\right]$ fluctuation. All experiments were conducted at room temperature $\left(25^{\circ} \mathrm{C}\right)$.

Stimuli and solutions. All stimuli and pharmacological agents were made in Tyrode's buffer (in mM as follows: $140 \mathrm{NaCl}, 5 \mathrm{KCl}, 2 \mathrm{CaCl}_{2}, 1$ $\mathrm{MgCl}_{2}, 10$ HEPES, 10 glucose, $10 \mathrm{Na}$-pyruvate, $5 \mathrm{NaHCO}_{3}, \mathrm{pH} 7.2,310$ $320 \mathrm{Osm}$ ) and applied at $\mathrm{pH}$ 7.2. For $\mathrm{Ca}^{2+}$-free Tyrode's solution, $\mathrm{MgCl}_{2}$ was substituted for $\mathrm{CaCl}_{2}$. CGRP and $\mathrm{CGRP}_{8-37}$ were obtained from Tocris Bioscience. Mianserin, suramin, thapsigargin, U73122, and WAY100635 were purchased from Sigma.

Isolated taste buds and taste cells were stimulated by bath perfusion of $\mathrm{KCl}$ (50 mM, substituted equimolar for $\mathrm{NaCl}$ ), taste mix (10 $\mu \mathrm{M}$ cyclohexamide, $1 \mathrm{~mm}$ sucralose, $0.1 \mathrm{~mm}$ SC45647, $1 \mathrm{~mm}$ denatonium), and CGRP $(0.1-100 \mu \mathrm{M})$. Stimuli were bath-applied for $30 \mathrm{~s}$ followed by return to buffer perfusion for at least 3-5 min between trials. This perfusion paradigm allows the stimuli to mix thoroughly within the recording chamber and to reach a final concentration in the bath followed by a complete washout. Moreover, this procedure produced reliable and consistent stimulus-evoked responses from isolated taste cells, as described previously (Huang et al., 2009, 2011a). Statistical analyses using paired 
A

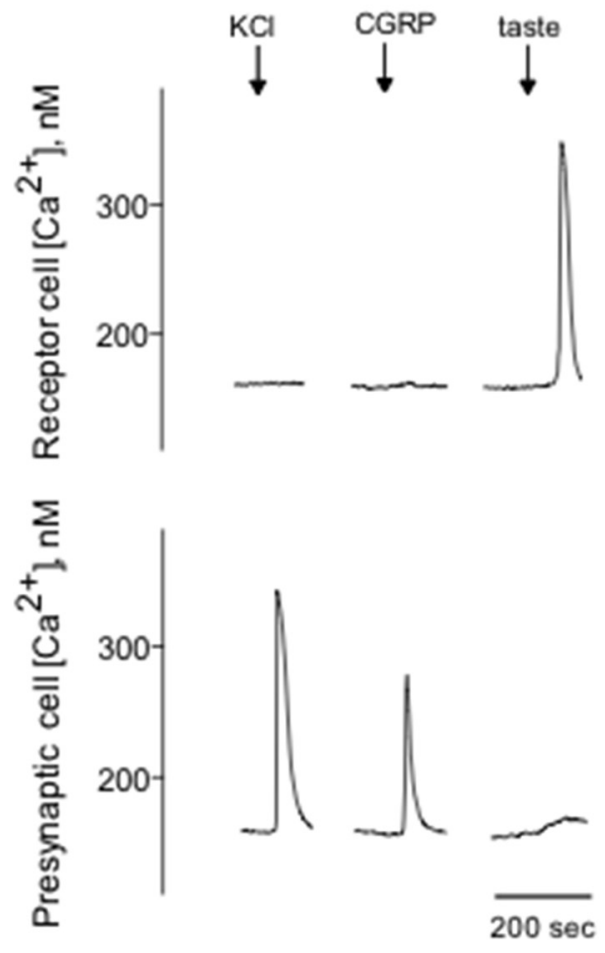

B

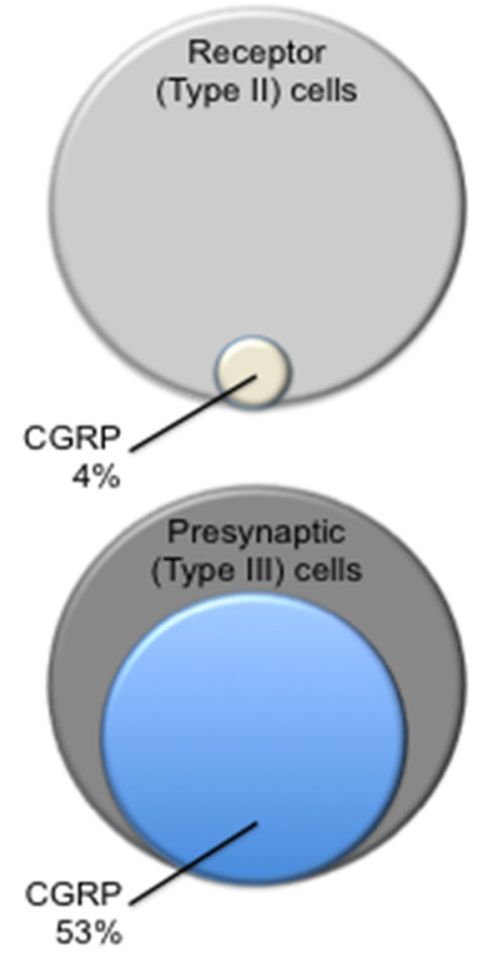

Figure 3. Presynaptic (Type III) taste cells respond to CGRP. A, Taste cells were isolated from vallate papillae and their responses to CGRP recorded by $\mathrm{Ca}^{2+}$ imaging. Traces represent $\mathrm{Ca}^{2+}$ recordings from an isolated Receptor (Type II) cell (top traces) and an isolated Presynaptic (Type III) cell (bottom traces). Representative traces of an identified Presynaptic (Type III) taste cell depolarized by KCI $(50 \mathrm{~mm})(\downarrow$, KCI) followed by stimulation with CGRP $(0.1 \mu \mathrm{M})$ ( $\downarrow$, CGRP). In marked contrast, a Receptor (Type II) cell showed a robust taste-evoked response ( $\downarrow$, taste) but absence of the response to CGRP. As shown in all records in this figure, $\mathrm{KCl}$ stimulation typically elicited more robust responses than for GGR. B , Venn diagrams representing the relative proportions of Receptor (Type II) and Presynaptic (Type III) taste cells that responded to CGRP.

Student's $t$ tests were applied to determine whether changes in responses following a given treatment were significant. Data presented in graphs show mean $\pm 95 \%$ CI.

Immunohistochemistry. Lingual tissues containing vallate papillae from mice were fixed with $4 \%$ PFA, cryoprotected, and cryosectioned at $20 \mu \mathrm{m}$ thickness and immunostained following the procedures as described by Vandenbeuch et al. (2013). Briefly, sections were washed with 0.01 M PBS, pH 7.2-7.4, and were incubated with $10 \%$ normal donkey serum for $1 \mathrm{~h}$ at room temperature. We used goat anti-CGRP (1:250) (AbD Serotec) for peripheral sensory fibers. Immunoreactivity of CGRP was determined by incubation with biotin-conjugated donkey anti-goat IgG (lot \#116297; Jackson ImmunoResearch Laboratories), followed by washing, and then a tyramide reaction using a tyramide signal amplification (TSA) kit with AlexaFluor-568 (lot \#1427590; Invitrogen; for details, see below). Negative controls were processed in parallel in every experiment with primary antibody omitted. No nonspecific fluorescence was detected (data not shown). Images were obtained with an Olympus Optical laser-scanning confocal microscope using Fluoview software.

Double staining for receptor component protein $(R C P)$ immunoreactivity and synaptosomal-associated protein 25 (SNAP25) immunoreactivity. Isolated taste buds were fixed in $4 \%$ PFA in PBS for $10-20$ min at $4^{\circ} \mathrm{C}$ and immunostained following the procedures as described previously (Huang et al., 2005). To localize two different antigens, RCP and SNAP25, in the isolated taste buds, a mixture of two primary antibodies generated in two different species against different antigens was used. The following specific primary antibodies then were applied to the isolated taste buds: chicken anti-RCP antiserum 1066 directed against the peptide with the sequence EEQIEALLHTVT conjugated to keyhole limpet hemocyanin (1:1000) for CGRP receptors (Rosenblatt et al., 2000; Pokabla et al., 2002; Morara et al., 2008), and rabbit anti-SNAP25 (1:1250-2500) (lot \#123M4764V; Sigma) for Presynaptic (Type IIII) cells. Immunoreactiv- ity of RCP was determined by incubation with biotin-conjugated donkey anti-chicken IgG (lot \#117066; Jackson ImmunoResearch Laboratories) followed by a tyramide reaction using a TSA kit with AlexaFluor-568 (lot \#1427590; Invitrogen). SNAP25 primary antibody binding using a donkey anti-rabbit secondary antibody conjugated with AlexaFluor-488 (lot \#1400413; Invitrogen) was revealed.

Briefly, fixed taste buds were washed with PBS and were blocked with 10\% normal donkey serum for $1 \mathrm{~h}$ at room temperature. Primary antibodies were applied to taste buds overnight at room temperature. Thereafter, for tyramide-based detection, after incubation in the primary antiserum, the taste buds were washed three times for 10 min each in PBS followed by incubation in a biotin-conjugated donkey anti-chicken secondary antibody (1: 200) (Jackson ImmunoResearch Laboratories) for $1 \mathrm{~h}$ at room temperature. The solutions from a Vectastain ABC kit (Vector Labs) were applied to the sections for $1 \mathrm{~h}$ at room temperature. After washes in PBS, a tyramide reaction using a TSA kit with AlexaFluor-568 (Invitrogen) was performed for $15 \mathrm{~min}$. Double immunostaining was performed after the tyramide reaction. Secondary antibody donkey antirabbit with AlexaFluor-488 (1:600) (Invitrogen) was applied to the taste buds for $0.5 \mathrm{~h}$ at room temperature. Taste buds were washed in PBS and coverslipped with Fluoromount (Invitrogen). Parenthetically, to validate the staining pattern, and to demonstrate the specificity, a second RCP antiserum [rabbit anti-RCP antiserum NY1047 directed against the peptide with the sequence GPEDEQSKSTSND (1:100500) (Bullock et al., 2014; Sardi et al., 2014)] was applied. Immunoreactivity of RCP was examined by using a donkey anti-rabbit secondary antibody conjugated with AlexaFluor-488 (1:600) (lot \#1400413; Invitrogen). The staining pattern is identical to that of taste buds processed with tyramide-based detection (data not shown). Negative controls were processed with the omission of RCP and SNAP25 primary antibodies. Alternatively, synthesizing RCP $(0.1 \mathrm{mg} / \mathrm{ml}$; United Biosystems) and SNAP25 peptides ( $0.5 \mathrm{mg} / \mathrm{ml}$; PEP-032, Invitrogen) were used in a blocking assay as follows: With the concentrations now matching, mix identical volumes $(20 \mu \mathrm{l})$ of the peptides and antibodies [RCP $(1: 10)$ and SNAP25 (1:10)] together at ambient temperature for 60 min on a rotator. In these control studies, neither RCP nor SNAP25 immunoreactivity was present. Images were obtained with an Olympus Optical laser-scanning confocal microscope using Fluoview software.

Antibody characterizations. The RCP antibody has been used and characterized in previous studies (Rosenblatt et al., 2000; Prado et al., 2001; Pokabla et al., 2002). By using the Western blot, the specificity of the antibody was examined in tissues and cell lines that express RCP.

Immunoelectron microscopy. Mice were perfused transcardially with the fixative containing $4 \%$ PFA plus $0.2 \%$ glutaraldehyde for immunoelectron microscopy. Vibratome sections $(50 \mu \mathrm{m})$ of lingual tissues were screened for taste buds under a dissecting microscope. Next, the lingual sections were incubated with the polyclonal goat anti-CGRP antibody (1:250) (AbD Serotec), washed in PBS, and then incubated with the biotinylated donkey anti-goat IgG (1:200) (Jackson ImmunoResearch Laboratories). After the DAB reaction, lingual sections were osmicated in $1 \% \mathrm{OsO}_{4}$ in $0.1 \mathrm{M}$ sodium cacodylate buffer. Serial thin sections (70-100 nm thick) were mounted on 200 mesh or formvar-coated single-slot grids and double-stained with uranyl acetate and lead citrate before being examined in an electron microscope (Hitachi, 7100). 


\section{Results}

CGRP-immunoreactive nerve fibers innervate taste buds

Immunofluorescence microscopy revealed that numerous fine nerve fibers showing intense CGRP immunoreactivity were distributed in the connective tissue below the taste buds (subgemmally) as well as within the lingual epithelial layer of the vallate papillae (Fig. 1). No stained cells were observed. These CGRPimmunoreactive fibers, with fine varicose axons penetrating the basement membrane and running within, or in close association with, taste buds (intragemmally) and coursing through the entire thickness of the epithelium, were frequently seen (Fig. 1B). Ultrastructural observations corroborated those of the light microscope showing intense CGRP immunoreactivity in nerve fibers. Similarly, immunoreactivity of the nerve processes was easily identified by electron microscopy, due to the intense electron-dense precipitate distributed diffusely throughout the cytoplasm of nerve processes. Presynaptic (Type III) cells, characterized by deep invaginated nuclei, many densecored vesicles and accumulation of clear vesicles at areas of the membrane specialization (Fig. 1C1), were identified as only taste cells forming ultrastructural specializations associated with synapses. Surprisingly, Figure 1C2 showed CGRP-immunoreactive nerve endings in apparent contact with Presynaptic (Type III) cells. At points of contact between immunoreactive nerve fibers and Presynaptic (Type III) taste cells, we observed numerous small clear vesicles within the nerve terminal as well as within the taste cell. At some of these contacts (Fig. 1C3), clear vesicles near the contact membrane and the membrane specialization were identified in the cytoplasm of the Presynaptic (Type III) cells. The total of 62 synapses between Presynaptic (Type III) cells and afferent nerve terminals were examined. Of these, 35 (56\%) were associated with CGRP-immunoreactive nerve terminals, whereas the remaining 27 appeared to be nonimmunoreactive. These findings suggest that some nerve endings receiving gustatory information express CGRP and may represent polymodal nociceptors.

\section{Taste bud cells express RCP}

\section{(a component of the CGRP receptor)}

To verify the expression of CGRP receptors in taste bud cells, we immunostained isolated and fixed vallate taste buds with an antibody directed against RCP, a component of the CGRP receptor, that is the functional link to the cellular signal transduction pathway, and analyzed the distribution of immunofluorescence by confocal microscopy. The cellular marker was present in isolated taste buds. To date, we have obtained 138 RCP-immunoreactive taste cells from 14 individually isolated taste buds. Figure 2 showed that several RCPimmunoreactive taste cells expressed SNAP25, suggesting that these Student's $t$ test). $N=6$.
B

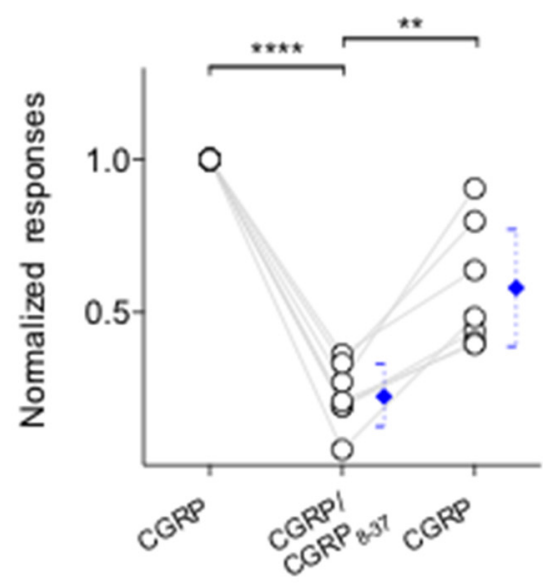

D

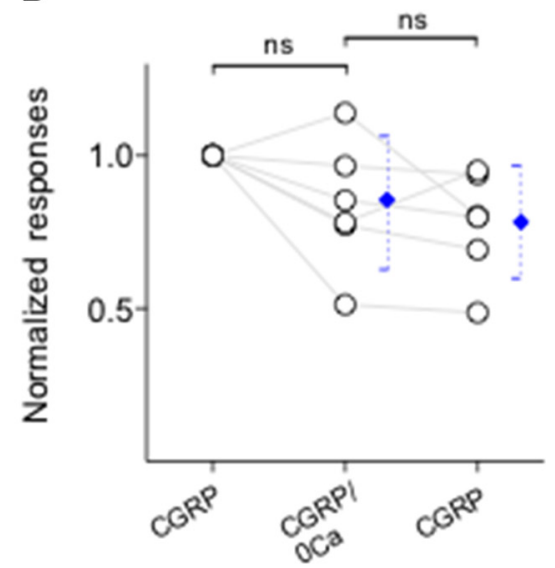

Figure 4. CGRP stimulates its receptors on Presynaptic (Type III) cells and induces $\mathrm{Ca}^{2+}$ release from intracellular stores. $\boldsymbol{A}$, Presynaptic (Type III) cells were initially stimulated with $\mathrm{KCI}(50 \mathrm{~mm})$ to verify their identity (data not shown). Bath application of CGRP $(0.1 \mu \mathrm{M})$ elicits $\mathrm{Ca}^{2+}$ mobilization in the taste cells ( $\downarrow$, CGRP). CGRP-induced $\mathrm{Ca}^{2+}$ responses were reversibly inhibited by sponses before, during, and after the presence of $\mathrm{CGRP}_{8-37}$. Points indicate normalized peak taste cell responses. Blue symbols represent mean $\pm 95 \%$ Cl. ${ }^{* *} p<0.01,{ }^{* * * *} p<0.0001$ (paired Student's $t$ test). $N=7$. C, CGRP-elicited Ca ${ }^{2+}$ mobilization in from the bathing solution ( 0 Ca, present throughout the shaded area). These findings indicated that (GRP-elicited responses in Presynaptic (Type III) cells were generated by release of the intracellular $\mathrm{Ca}^{2+}$, consistent with the excitation of GPCR. D, Summary of experiments testing sources of CGRP-elicited $\mathrm{Ca}^{2+}$ mobilization, plotted as in C. ns, Not significant (paired

are Presynaptic (Type III) cells expressing RCP. On the contrary, some RCP-immunoreactive taste cells lack SNAP25, suggesting other types of taste cells may express RCP as well. Of 100 taste bud cells that showed SNAP25 immunoreactivity, 46 taste bud cells were also labeled by RCP antiserum (Fig. 2C). Nevertheless, immunostaining for CGRP-immunoreactive nerve fibers revealed that CGRP-containing axons came into apposition with taste cells expressing RCP. We anticipated that CGRP might be likely released from these fibers onto taste cells (Nagai et al., 1996; Finger and Simon, 2002; Simon et al., 2003). Next, we refined these findings to examine whether and how CGRP affects taste cells isolated from mouse vallate papillae.

\section{CGRP elicits $\mathrm{Ca}^{2+}$ mobilization in taste cells}

To determine whether activation of CGRP receptors present on mouse taste cells can cause physiological responses, functional imaging was conducted on isolated taste cells loaded with the $\mathrm{Ca}^{2+}$-sensitive dye, Fura-2. Concentration-response 
A

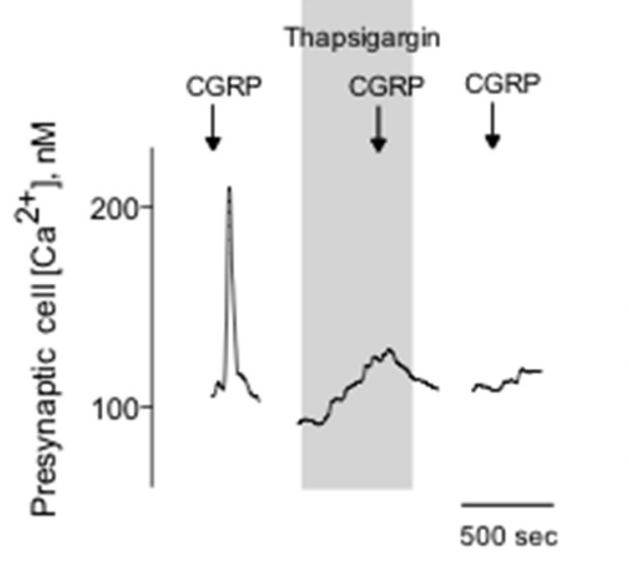

C

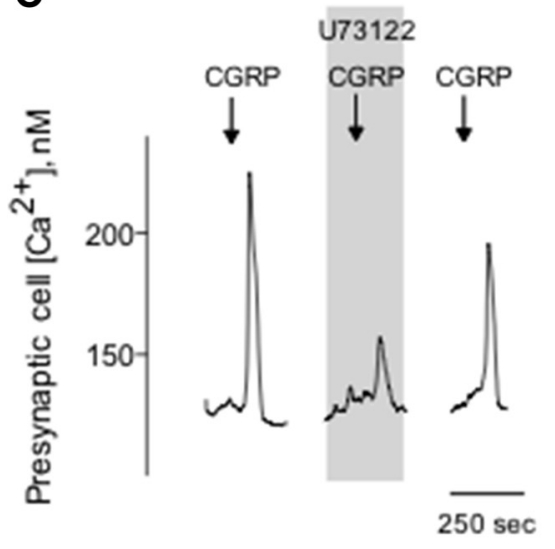

B

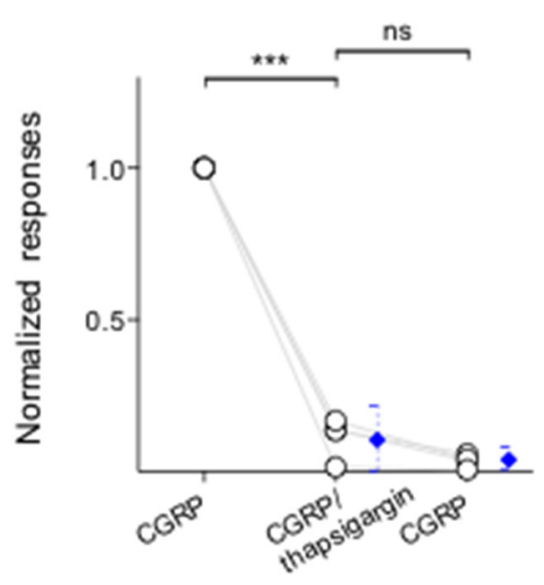

D

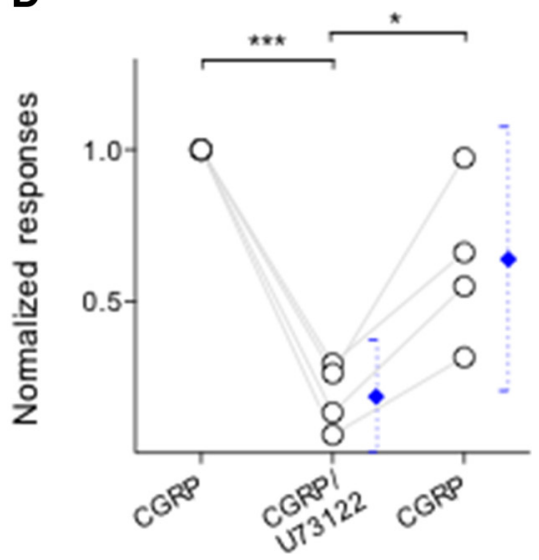

Figure 5. Intracellular $\mathrm{Ca}^{2+}$ release in Presynaptic (Type III) cells is via a PLC-mediated pathway. A, Presynaptic (Type III) cells were initially stimulated with $\mathrm{KCl}(50 \mathrm{~mm})$ to verify its identity (data not shown). Bath application of CGRP (0.1 $\mu \mathrm{M})$ elicits $\mathrm{Ca}^{2+}$ mobilization in the taste cell ( $\downarrow$, CGRP). Treating Presynaptic (Type III) cells with thapsigargin (1 $\mu \mathrm{M})$, a SER Ca-ATPase inhibitor (present throughout the shaded area), irreversibly reduced $\mathrm{Ca}^{2+}$ responses evoked by CGRP, consistent with $\mathrm{Ca}^{2+}$ store release mechanisms for these stimuli. $\boldsymbol{B}$, Summary of CGRP-elicited $\mathrm{Ca}^{2+}$ responses before, during, and after the presence of thapsigargin. Points indicate normalized peak taste cell responses. Blue symbols represent mean $\pm 95 \% \mathrm{Cl}^{*}{ }^{* *} p<0.001$ (paired Student's $t$ test). $N=4$. ns, Not significant. C, CGRP-elicited $\mathrm{Ca}^{2+}$ mobilization in an isolated Presynaptic (Type III) cell, identified by its responses to $\mathrm{KCl}$, but not taste, was blocked when U73122 $(10 \mu \mathrm{M})$ (present throughout the shaded area) was present in the bathing solution. Consistent with the blockage of PLC-mediated cascade, these findings indicated that CGRP-elicited responses in Presynaptic (Type III) cells were due to $\mathrm{Ca}^{2+}$ release from intracellular stores. $\boldsymbol{D}$, Summary of experiments plotted as in $\mathbf{C}$. $p<$ $0.05,{ }^{* * *} p<0.001$ (paired Student's $t$ test). $N=4$.

relations for taste cells indicated that $\mathrm{EC}_{50}$ for CGRP was 0.16 $\mu \mathrm{M}$. Bath-applied CGRP using the lower concentration of receptor agonist (e.g., $0.1 \mu \mathrm{M}$ CGRP) induced robust $\mathrm{Ca}^{2+}$ responses in a subset of taste cells. Meanwhile, isolated taste cells were identified as Receptor (Type II) or Presynaptic (Type III) cells based on their responses to taste stimulation or $\mathrm{KCl}$ depolarization, respectively (Fig. $3 A$ ) (DeFazio et al., 2006; Huang et al., 2007; Huang et al., 2009, 2011a, 2012; Vandenbeuch et al., 2010). Approximately 13\% of isolated taste cells (41 of 315) exhibited $\mathrm{Ca}^{2+}$ responses when stimulated with bath-applied CGRP $(0.1 \mu \mathrm{M})$. Of the cells identified as Receptor (Type II) cells, only $\sim 4 \%$ ( 1 of 26 ) showed $\mathrm{Ca}^{2+}$ responses to CGRP. In marked contrast, 53\% of the Presynaptic (Type III) cells (40 of 75) responded to CGRP, in good correspondence with that of Presynaptic (Type III) cells expressing RCP in the double-immunostaining studies. Figure $3 B$ depicts the summary of these series of experiments and shows the relative proportions of taste cells that respond to CGRP.

\section{Elevated $\mathrm{Ca}^{2+}$ releases from intracellular stores}

We next conducted a series of experiments to test the effects of CGRP on Presynaptic (Type III) cells and to explore the source of $\mathrm{Ca}^{2+}$ transients during the peptidergic stimulation. We initiated these experiments using $\mathrm{KCl}$ (50 mM) to identify Presynaptic (Type III) cells followed by CGRP bath application. Calcium responses elicited by CGRP $(0.1 \mu \mathrm{M})$ were significantly and reversibly abolished by $\mathrm{CGRP}_{8-37}$, a CGRP receptor antagonist (Fig. $4 A, B$ ). In addition, taste cells showed the robust $\mathrm{Ca}^{2+}$ mobilization in response to CGRP when $\mathrm{Ca}^{2+}$ in the medium was replaced with $\mathrm{Mg}^{2+}(0 \mathrm{Ca})$ (Fig. $\left.4 C, D\right)$, consistent with coupling of CGRP receptors to intracellular $\mathrm{Ca}^{2+}$ store release. Thus, we explored whether thapsigargin, a sarcoplasmic/endoplasmic reticulum $\mathrm{Ca}^{2+}$-ATPase inhibitor, that depletes intracellular $\mathrm{Ca}^{2+}$ stores, abolishes $\mathrm{Ca}^{2+}$ transients in CGRP stimulated Presynaptic (Type III) cells. Thapsigargin ( $1 \mu \mathrm{M}, 5-10 \mathrm{~min})$ significantly and irreversibly reduced $\mathrm{Ca}^{2+}$ transients in the isolated Presynaptic (Type III) cells (Fig. 5A,B). Next, we also tested whether U73122, a broadspectrum phospholipase C (PLC) blocker, affects $\mathrm{Ca}^{2+}$ transients in CGRP stimulated Presynaptic (Type III) cells. Indeed, U73122 (10 $\mu \mathrm{M})$ significantly and reversibly reduced CGRPevoked $\mathrm{Ca}^{2+}$ responses in taste cells (Fig. 5C,D). This clearly differs from the frank $\mathrm{Ca}^{2+}$ influx stimulated by $\mathrm{KCl}$ depolarization as described in the present study and those of the previous studies (Huang et al., 2007; Huang et al., 2009, 2012; Vandenbeuch et al., 2010). Collectively, these findings strongly suggest that CGRP activates its receptors and subsequently elicits $\mathrm{PLC} / \mathrm{IP}_{3}$-mediated $\mathrm{Ca}^{2+}$ release from intracellular stores.

\section{CGRP triggers 5-HT release from taste buds}

Taste buds, specifically Presynaptic (Type III) cells, secrete the transmitter 5-HT when stimulated with tastants (Huang et al., 2007; Huang et al., 2009, 2011a, 2012). Conceivably, in the present study, because CGRP specifically activates Presynaptic (Type III) cells, we tested whether CGRP induces taste buds to release 5 -HT. Using $\mathrm{CHO}$ biosensors expressing $5-\mathrm{HT}_{2 \mathrm{C}}$ receptors (Fig. $6 \mathrm{~A}$ ), we showed that depolarizing taste buds with $50 \mathrm{mM} \mathrm{KCl}$ triggered 5-HT secretion, as previously demonstrated (Huang et al., 2005; Huang et al., 2008b, 2012). To date, we have obtained successful biosensor recordings from 26 of 89 taste buds when testing $\mathrm{KCl}$ depolarization. The success rate of measuring 5-HT release in these experiments was $29 \%$, in good correspondence with values reported previously (Huang et al., 2005). Of 26 taste buds that secreted $5-\mathrm{HT}$ in response to $\mathrm{KCl}$ depolarization, 11 
taste buds also released 5-HT when stimulated with $0.1 \mu \mathrm{M}$ CGRP (Fig. 6B). $\mathrm{Ca}^{2+}$ responses in biosensor cells detecting CGRP-elicited 5-HT release were corroborated by mianserin, a $5-\mathrm{HT}_{2 \mathrm{C}}$ receptor blocker, as demonstrated previously (Huang et al., 2005), indicating the activation of serotonergic receptors on biosensors (data not shown). To verify that the agonist was activating its cognate receptors on taste cells, and subsequently elicit transmitter release, and thus 5-HT, we applied CGRP $_{8-37}(0.2 \mu \mathrm{M})$ in the bath solution. $\mathrm{CGRP}_{8-37}$ significantly and reversibly decreased CGRP-induced 5-HT release from isolated taste buds (Fig. $6 B, C)$. In the absence of taste buds, 5 -HT biosensors did not respond to any of the compounds used for this study except, of course, for 5-HT. In addition, 5-HT biosensor cells retained full receptor agonist sensitivity in the presence of $\mathrm{CGRP}_{8-37}$ used in this study (data not shown).

\section{CGRP inhibits ATP signaling in taste buds}

ATP is thought to be an important excitatory transmitter between taste buds and gustatory sensory afferent fibers (Finger et al., 2005; Huang et al., 2011b; Vandenbeuch et al., 2015). In a separate series of experiments, we measured taste-evoked ATP secretion from Receptor (Type II) cells within taste buds, as described previously (Huang et al., 2007; Huang et al., 2009, 2012; Romanov et al., 2007; Murata et al., 2010; Dvoryanchikov et al., 2011). Stimulating isolated taste buds with taste mix (10 $\mu$ M cycloheximide, $1 \mathrm{~mm}$ sucralose, $0.1 \mathrm{~mm}$ SC45647, 1 mM denatonium) evoked ATP secretion. Suramin, a broadspectrum $\mathrm{P} 2$ receptor antagonist, was used to verify the responses in ATP biosensor cells that were generated by activation of the P2X receptors expressed on biosensors (Huang et al., 2007) (data not shown). The success rate of measuring taste-evoked ATP secretion in these experiments was 9\% (12 of 127), in good correspondence with values reported previously (Huang et al., 2007). Our recent study has demonstrated that 5-HT, released from Presynaptic (Type III) cells during taste stimulation, reduces ATP secretion (Huang et al., 2009). This serotonergic inhibition is generated by the activation of $5-\mathrm{HT}_{1 \mathrm{~A}}$ receptors expressed on Receptor (Type II) cells (Kaya et al., 2004; Huang et al., 2009; Jaber et al., 2014). Because CGRP triggers 5-HT secretion from Presynaptic (Type III) cells within taste buds (Fig. 6B) and because 5-HT inhibits Receptor (Type II) cells (Huang et al., 2009), we tested whether the net effect of CGRP stimulation depresses ATP secretion from intact taste buds during taste stimulation. If so, this would suggest that the ultimate function of CGRP would be to decrease the gustatory responses in taste buds, providing proof of concept. As we predicted, CGRP significantly and reversibly reduced ATP secretion evoked by a sweet/bitter taste mix. Importantly, the mechanism of the inhibition of CGRP-induced reduction of ATP secretion evoked by taste stimuli was corroborated by WAY100635 (10 nM), a 5- $\mathrm{HT}_{1 \mathrm{~A}}$ receptor antagonist (Fig. 7). These results suggest that the inhibitory actions of CGRP on ATP secretion were indirectly mediated, at least in part, by 5 -HT.

\section{Discussion}

The main findings of the present study are as follows: (1) nerve terminals forming synaptic contacts with Presynaptic (Type III) taste cells contain CGRP; (2) CGRP activates its receptors on Presynaptic (Type III) cells leading to the activation of PLCinitiated cascade, and to the release of calcium from intracellular stores; (3) CGRP applying to the bath medium evokes 5-HT release from vallate taste buds; and (4) the net effect of CGRP stimulation reduces ATP secretion during taste stimulation.

Tissue-specific signaling events are associated with the specific intracellular coupling and receptor phenotypes for the CGRP receptors because CGRP operates via GPCRs (Juaneda et al., 2000; Walker et al., 2010). Generally speaking, activation of the CGRP receptors results in $\mathrm{G} \alpha_{\mathrm{s}}$-mediated activation of adenylate cyclase, with a subsequent increase in cAMP and activation of protein kinase A (Hay et al., 2003). In addition, the CGRP receptors can couple to mitogen-activated protein kinase activation, and nitric oxide production, as well as a host of transcriptional events (Walker et al., 2010). Moreover, it is expected that the CGRP receptors can couple either to $\mathrm{G} \alpha_{\mathrm{q} / 11}$-mediated PLC $\beta 1$ proteins (Drissi et al., 1998) or to $\mathrm{G} \alpha_{\mathrm{s}}$-mediated PLC $\varepsilon$, an en- 
A

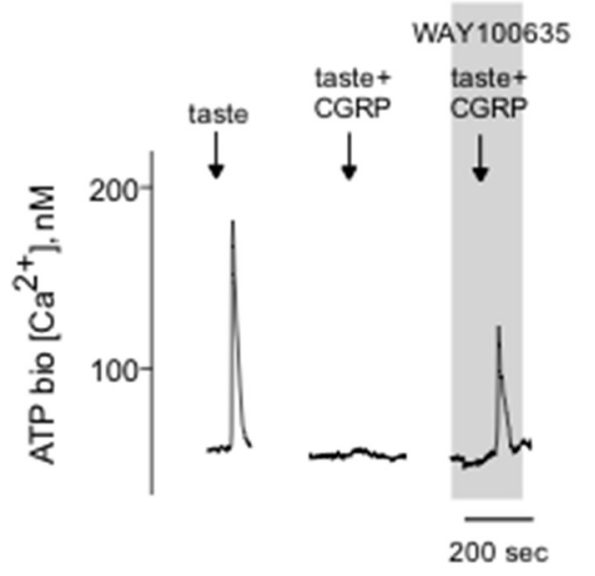

B

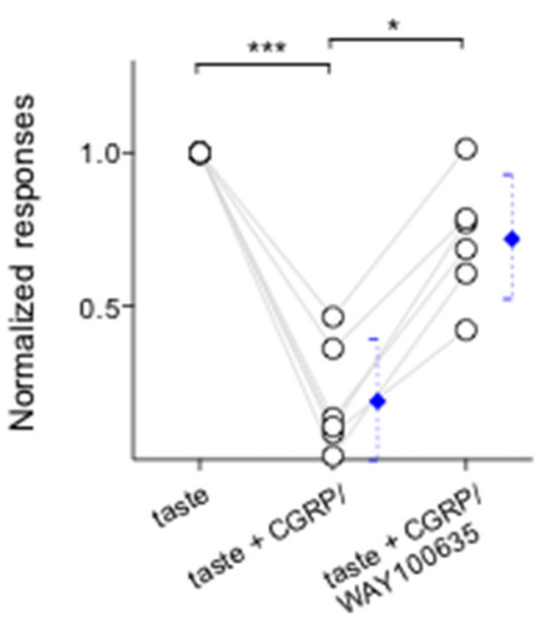

Figure 7. CGRP inhibits ATP secretion from taste buds. CHO/ATP ${ }_{P_{2 \times 2} / P_{2 \times 3}}$ cells (hereafter called ATP biosensors) were used to monitor taste-evoked ATP secretion from isolated taste buds. The extracellular 5-HT inhibits Receptor (Type II) cells (Huang et al., 2009). Whole taste buds were isolated from mouse vallate papillae to retain cell-to-cell communication between Receptor (Type II) and Presynaptic (Type III) cells. A, Traces represent robust responses from the biosensor positioned against an isolated taste bud when the taste bud was stimulated by a sweet-bitter taste mix ( $\downarrow$, taste; $1 \mathrm{~mm}$

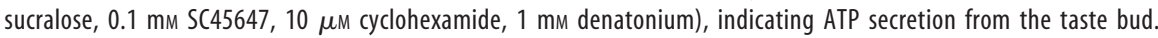
Taste-evoked ATP secretion was inhibited by $0.1 \mu \mathrm{m}$ (GRP ( $\downarrow$, taste + (GRP). Adding WAY100635 (0.01 $\mu \mathrm{M})$, a 5-HT 1 A receptor blocker, to the bath (present throughout the shaded area) rescued CGRP-inhibited ATP secretion, suggesting that CGRP plays as an inhibitory transmitter via the serotonergic signaling in taste buds. $\boldsymbol{B}$, Summary of CGRP-inhibited taste-evoked ATP secretion before and during the presence of WAY100635. Points indicate normalized peak biosensor responses. Blue symbols represent mean $\pm 95 \%\left(\mathrm{Cl} .{ }^{*} p<0.05,{ }^{* * *} p<0.001\right.$ (paired Student's $t$ test). $N=6$.

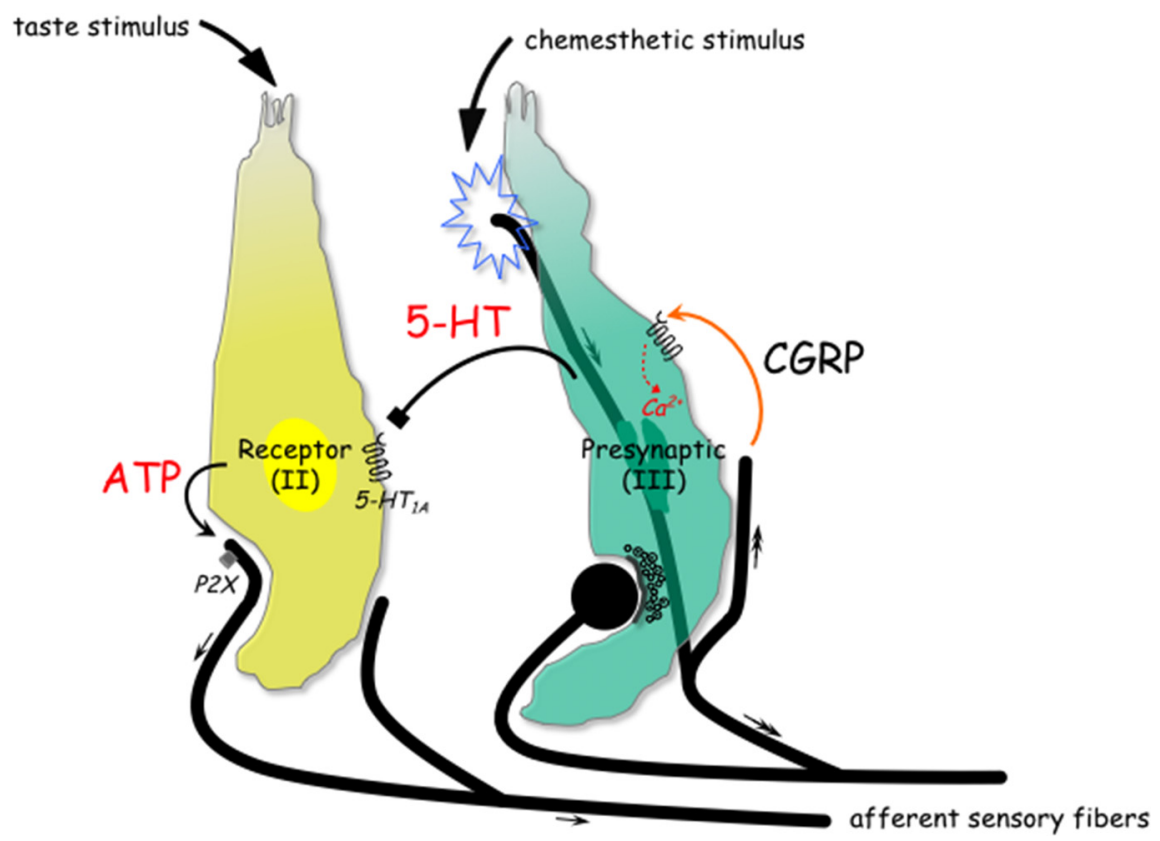

Figure 8. Schematic drawing represents the postulated scenario of CGRP, a putative efferent transmitter, in taste buds. Two distinct types of taste cells are shown. During taste stimulation, ATP activates gustatory afferent fibers that propagate taste signals (small arrows) to the brain (Finger et al., 2005; Huang et al., 2007; Jaber et al., 2014; Vandenbeuch et al., 2015). Chemesthetic stimulation activates sensory afferent fibers that propagate signals centrally (double-headed arrows) and have the ability to release the stored transmitter. (GRP may be directly released from the activated afferent axon branches (orange curved arrow). The activation of the (GRP receptors triggers Presynaptic (Type III) cells to elevate intracellular $\mathrm{Ca}^{2+}$ transients and to secrete 5-HT, which inhibits ATP release from Receptor (Type II) cells via serotonergic signaling pathways (black symbol) (Huang et al., 2009). Collectively, the peptidergic actions in taste buds could necessarily imply the complex interplay between taste cells and peripheral sensory neurons that becomes more important during the processing of the gustatory information.

zyme responsible for the cAMP-induced $\mathrm{Ca}^{2+}$ release from intracellular stores (Morara et al., 2008). Ceruti et al. (2011) reported that trigeminal neurons showed no increase in their intracellular $\mathrm{Ca}^{2+}$ transient after CGRP exposure, suggesting that the predominant secondary messenger system in these neurons is likely represented by adenylyl cyclase as reported previously. Nevertheless, our data showed that PLCcoupled CGRP receptors are functional on Presynaptic (Type III) cells in vallate taste papillae.

The receptor for CGRP and adrenomedullin requires an intracellular peripheral membrane protein named CGRP RCP for signaling. Recent studies reported that RCP enables signaling by binding directly to the receptor; thus, immunostaining for RCP can be used to identify sites of CGRP receptors (Morara et al., 2008; Dickerson, 2013; Bullock et al., 2014). In the present study, indeed, we clearly showed that Presynaptic (Type III) cells express RCP. Receptor (Type II) cells may also express RCP because many taste cells showing RCP immunoreactivity do not express SNAP25. It remains to be seen whether providing such staining pattern by immunostaining Receptor (Type II) cell marker makes sense of that overlapping with RCP.

Pharmacology revealed that CGRP stimulates its GPCRs and evokes $\mathrm{Ca}^{2+}$ responses in Presynaptic (Type III) taste cells because the intracellular $\mathrm{Ca}^{2+}$ transients are inhibited by $\mathrm{CGRP}_{8-37}$, a CGRP receptor antagonist. Importantly, CGRP also stimulate taste bud cells to secrete 5-HT, a Presynaptic (Type III) cell transmitter (Huang et al., 2007). Parenthetically, ATP, an excitatory transmitter released from Receptor (Type II) cells via novel mechanisms, likely secretion through pannexin1 hemichannels (Huang et al., 2007; Romanov et al., 2007) or a voltage-gated ion channel, calcium homeostasis modulator 1 (CALHM1) (Taruno et al., 2013), is now widely acknowledged as the main gustatory neurotransmitter within taste buds, acting on $\mathrm{P} 2 \mathrm{X}$ receptors on afferent nerve fiber terminals (Bo et al., 1999; Finger et al., 2005; Huang et al., 2011b; Vandenbeuch et al., 2015). Several studies reported that P2X channels display high rates of desensitization (Cook and McCleskey, 1997; He et al., 2002; Rettinger and Schmalzing, 2004). We postulated that, by regulating ATP release through its release channels, such desensitization would be prevented, thus facilitating gustatory signals. Supporting this notion is that taste-evoked ATP secretion was inhibited by paracrine activation of $5-\mathrm{HT}_{1 \mathrm{~A}}$ re- 
ceptors (Herness and Chen, 1997; Kaya et al., 2004; Huang et al., 2009; Jaber et al., 2014) and, alternatively, was enhanced by blocking 5-HT $1 \mathrm{~A}$ with WAY100635 (Huang et al., 2009). Therefore, we anticipate that altering 5-HT within taste buds may shape taste sensitivity. Indeed, the alteration of 5-HT signaling significantly affects the taste thresholds for sweet as well as bitter tastes in human subjects (Heath et al., 2006) and the chorda tympani neural responses to taste stimuli in rats (Jaber et al., 2014). Nevertheless, our results showed that the net effect of peptidergic inputs is to initiate serotonergic inhibition within taste buds, and to reduce taste-evoked release of ATP. Collectively, these data suggest that CGRP alters taste signal transduction and transmission during gustatory stimulation.

CGRP-immunoreactive nerve fibers forming subgemmal plexuses in the mouse vallate papillae may represent the emerging idea that the taste bud is not a mere receptor unit but also a highly sophisticated information processing and integration unit by which taste buds can communicate with each other (Roper, 1989; Huang et al., 2003; Crescimanno et al., 2004). Electrophysiology revealed that branching sensory afferent fibers innervating several neighboring taste buds appear to mediate inhibitory peripheral interpapillary interactions (Murayama, 1988; Riddle et al., 1990; Vandenbeuch et al., 2004). Presently, our findings may provide one of the convincing explanations for the mechanisms underlying this inhibition. Indeed, much evidence is now available that sensory neurons, which are excited by the environmental stimulus, have the ability to release the stored transmitter (Maggi and Meli, 1988; Silverman and Kruger, 1989; Ishida et al., 2002; Simon et al., 2003). Specifically, our findings may explain a scenario that actions of CGRP on taste bud cells imply playing an inhibitory role for some of these peptidergic afferent axons in taste sensitivity.

Previous studies have indicated that lingual epithelia are rich in CGRP-containing (Finger, 1986; Astbäck et al., 1997; Ishida et al., 2002; Huang et al., 2003) and substance P (SP)-containing (Nagy et al., 1982; Nishimoto et al., 1982; Yamasaki et al., 1984; Finger, 1986; Astbäck et al., 1997; Ishida et al., 2002) nerve fibers, especially in those areas where taste buds can be expected. These populations of sensory fibers mostly express TRPV1 receptors for chemesthetic activators, such as capsaicin, and a variety of other strong oral irritants (Ishida et al., 2002). The most likely source of the CGRP fibers in the taste bud is as polymodal nociceptors, many of which express both CGRP and SP. Their actions involved in the modulation of taste transmission have been studied recently. Specifically, the taste transmitter evoked by SP remains unknown, but the activation of SP receptor NK-1R had an additive effect on $\mathrm{Ca}^{2+}$ responses evoked by umami stimuli in Receptor (Type II) cells (Grant, 2012). Similarly, the unique feature of CGRP is that it appears to primarily affect Presynaptic (Type III) cells and elicits a signaling molecule, namely, 5-HT. Furthermore, the full effect of CGRP in terms of taste perception has been revealed.

Parenthetically, glutamate is associated with the inhibitory taste transmission as well and likely to resemble secretion of glutamate from peripheral terminals of nerve fibers (Willis, 1999; Vandenbeuch et al., 2010; Huang et al., 2012). Vandenbeuch et al. (2010) showed that the majority of glutamate-containing nerve fibers in taste buds express P2X2, a marker for gustatory fibers, thus suggesting a gustatory origin (Ishida et al., 2009). Our results extended the previous study showing the extensive innervation of CGRP-immunoreactive nerve fibers, which coexpress TRPV1 in vallate taste papillae (Ishida et al., 2002), and demonstrated that their stored transmitter regulates taste signaling within taste buds. Collectively, an interpretation of the peptidergic action within taste buds is that it appears to be important chemesthetic regulations of gustatory signal transmission, as theoretically may relate to the processing of the gustatory information. Figure 8 summarizes this postulated scenario in the schematic taste bud.

Last, although the pathophysiology of inflammatory diseases, including asthma (Cardell et al., 1994), psoriasis (Reich et al., 2007), and migraine (Ceruti et al., 2011), is not completely understood, activation of the nociceptive sensory system leading to CGRP release is likely to play a role (Arulmani et al., 2004). Unexpectedly, taste abnormality occurs in approximately onefourth of migraineurs during an acute migraine attack (Kelman, 2004). Despite the significant advances that the field has experienced in the last decade, we still do not have a good understanding of pathophysiology of the mechanisms that lead to aberrant taste during several inflammatory diseases, at least in migraine. Nevertheless, our data may suggest an explanation that inflammation-induced elevation of CGRP secretion from the peripheral terminals of the glossopharyngeal nerves reduces the taste signals via serotonergic paths before their transmission to the gustatory sensory fibers and then to the brain. Although intriguing, it is beyond the scope of the present study to investigate the pathophysiology in any detail.

In conclusion, our results obtained in immunohistochemistry at light microscopic and electron microscopic levels on lingual tissues as well as $\mathrm{Ca}^{2+}$ imaging from isolated taste buds suggest that one of the primary roles of CGRP secreted from the peripheral sensory nerve terminals within taste buds is to shape taste signals before their transmission of the final output, and this modulation likely occurs by modulating the release of the gustatory neurotransmitter ATP from $5-\mathrm{HT}_{1 \mathrm{~A}}$-expressing Receptor (Type II) cells. Furthermore, our data also suggest that the complex interplay between taste cells and chemosensory neurons may play an important role during the processing of the complex stimuli involving both spicy and tasty components.

\section{References}

Arulmani U, Maassenvandenbrink A, Villalón CM, Saxena PR (2004) Calcitonin gene-related peptide and its role in migraine pathophysiology. Eur J Pharmacol 500:315-330. CrossRef Medline

Astbäck J, Arvidson K, Johansson O (1997) An immunohistochemical screening of neurochemical markers in fungiform papillae and taste buds of the anterior rat tongue. Arch Oral Biol 42:137-147. CrossRef Medline

Berg KA, Clarke WP, Sailstad C, Saltzman A, Maayani S (1994) Signal transduction differences between 5-hydroxytryptamine type $2 \mathrm{~A}$ and type $2 \mathrm{C}$ receptor systems. Mol Pharmacol 46:477-484. Medline

Bo X, Alavi A, Xiang Z, Oglesby I, Ford A, Burnstock G (1999) Localization of ATP-gated P2X2 and P2X3 receptor immunoreactive nerves in rat taste buds. Neuroreport 10:1107-1111. CrossRef Medline

Bullock CM, Wookey P, Bennett A, Mobasheri A, Dickerson I, Kelly S (2014) Peripheral calcitonin gene-related peptide receptor activation and mechanical sensitization of the joint in rat models of osteoarthritis pain. Arthritis Rheumatol 66:2188-2200. CrossRef Medline

Cao Y, Zhao FL, Kolli T, Hivley R, Herness S (2009) GABA expression in the mammalian taste bud functions as a route of inhibitory cell-to-cell communication. Proc Natl Acad Sci U S A 106:4006-4011. CrossRef Medline

Cardell LO, Uddman R, Edvinsson L (1994) Low plasma concentrations of VIP and elevated levels of other neuropeptides during exacerbations of asthma. Eur Respir J 7:2169-2173. CrossRef Medline

Ceruti S, Villa G, Fumagalli M, Colombo L, Magni G, Zanardelli M, Fabbretti E, Verderio C, van den Maagdenberg AM, Nistri A, Abbracchio MP (2011) Calcitonin gene-related peptide-mediated enhancement of purinergic neuron/glia communication by the algogenic factor bradykinin in mouse trigeminal ganglia from wild-type and R192Q Cav2.1 Knock-in mice: implications for basic mechanisms of migraine pain. J Neurosci 31:3638-3649. CrossRef Medline

Chang RB, Waters H, Liman ER (2010) A proton current drives action po- 
tentials in genetically identified sour taste cells. Proc Natl Acad Sci U S A 107:22320-22325. CrossRef Medline

Chaudhari N, Roper SD (2010) The cell biology of taste. J Cell Biol 190: 285-296. CrossRef Medline

Cook SP, McCleskey EW (1997) Desensitization, recovery and $\mathrm{Ca}^{2+-}$ dependent modulation of ATP-gated P2X receptors in nociceptors. Neuropharmacology 36:1303-1308. CrossRef Medline

Crescimanno C, Merigo F, Bernardi P, Osculati F, Sbarbati A (2004) Neurochemistry of the gustatory subgemmal plexus. Chem Senses 29: 537-546. CrossRef Medline

DeFazio RA, Dvoryanchikov G, Maruyama Y, Kim JW, Pereira E, Roper SD, Chaudhari N (2006) Separate populations of receptor cells and presynaptic cells in mouse taste buds. J Neurosci 26:3971-3980. CrossRef Medline

Dickerson IM (2013) Role of CGRP-receptor component protein (RCP) in CLR/ RAMP function. Curr Protein Pept Sci 14:407-415. CrossRef Medline

Drissi H, Lasmoles F, Le Mellay V, Marie PJ, Lieberherr M (1998) Activation of phospholipase C-beta1 via Galphaq/11 during calcium mobilization by calcitonin gene-related peptide. J Biol Chem 273:20168-20174. CrossRef Medline

Dvoryanchikov G, Tomchik SM, Chaudhari N (2007) Biogenic amine synthesis and uptake in rodent taste buds. J Comp Neurol 505:302-313. CrossRef Medline

Dvoryanchikov G, Huang YA, Barro-Soria R, Chaudhari N, Roper SD (2011) GABA, its receptors, and GABAergic inhibition in mouse taste buds. J Neurosci 31:5782-5791. CrossRef Medline

Finger TE (1986) Peptide immunohistochemistry demonstrates multiple classes of perigemmal nerve fibers in the circumvallate papilla of the rat. Chem Senses 11:135-144. CrossRef

Finger TE, Simon SA (2002) The cell biology of lingual epithelia. In: The neurobiology of taste and smell (Finger TE, Silver WL, Restrepo D, eds), pp 287-314. New York: Wiley.

Finger TE, Danilova V, Barrows J, Bartel DL, Vigers AJ, Stone L, Hellekant G, Kinnamon SC (2005) ATP signaling is crucial for communication from taste buds to gustatory nerves. Science 310:1495-1499. CrossRef Medline

Grant J (2012) Tachykinins stimulate a subset of mouse taste cells. PLoS One 7:e31697. CrossRef Medline

Green BG (2012) Chemesthesis and the chemical senses as components of a "chemofensor complex." Chem Senses 37:201-206. CrossRef

Grynkiewicz G, Poenie M, Tsien RY (1985) A new generation of $\mathrm{Ca}^{2+}$ indicators with greatly improved fluorescence properties. J Biol Chem 260: 3440-3450. Medline

Hay DL, Poyner DR, Smith DM (2003) Desensitisation of adrenomedullin and CGRP receptors. Regul Pept 112:139-145. CrossRef Medline

Hayakawa T, Kuwahara S, Maeda S, Tanaka K, Seki M (2010) Calcitonin gene-related peptide immunoreactive neurons innervating the soft palate, the root of tongue, and the pharynx in the superior glossopharyngeal ganglion of the rat. J Chem Neuroanat 39:221-227. CrossRef Medline

Hayakawa T, Kuwahara-Otani S, Maeda S, Tanaka K, Seki M (2014) Calcitonin gene-related peptide immunoreactive sensory neurons in the vagal and glossopharyngeal ganglia innervating the larynx of the rat. J Chem Neuroanat 55:18-23. CrossRef Medline

He ML, Koshimizu TA, Tomić M, Stojilkovic SS (2002) Purinergic P2X2 receptor desensitization depends on coupling between ectodomain and C-terminal domain. Mol Pharmacol 62:1187-1197. CrossRef Medline

Heath TP, Melichar JK, Nutt DJ, Donaldson LF (2006) Human taste thresholds are modulated by serotonin and noradrenaline. J Neurosci 26: 12664-12671. CrossRef Medline

Herness S, Chen Y (1997) Serotonin inhibits calcium-activated $\mathrm{K}^{+}$current in rat taste receptor cells. Neuroreport 8:3257-3261. CrossRef Medline

Herness S, Zhao FL (2009) The neuropeptides CCK and NPY and the changing view of cell-to-cell communication in the taste bud. Physiol Behav 97:581-591. CrossRef Medline

Holzer P (1988) Local effector functions of capsaicin-sensitive sensory nerve endings: involvement of tachykinins, calcitonin gene-related peptide and other neuropeptides. Neuroscience 24:739-768. CrossRef Medline

Huang AL, Chen X, Hoon MA, Chandrashekar J, Guo W, Tränkner D, Ryba NJ, Zuker CS (2006) The cells and logic for mammalian sour taste detection. Nature 442:934-938. CrossRef Medline

Huang YA, Maruyama Y, Roper SD (2008a) Norepinephrine is coreleased with serotonin in mouse taste buds. J Neurosci 28:13088-13093. CrossRef Medline

Huang YA, Maruyama Y, Stimac R, Roper SD (2008b) Presynaptic (Type III) cells in mouse taste buds sense sour (acid) taste. J Physiol 586: 2903-2912. CrossRef Medline

Huang YA, Dando R, Roper SD (2009) Autocrine and paracrine roles for ATP and serotonin in mouse taste buds. J Neurosci 29:13909-13918. CrossRef Medline

Huang YA, Pereira E, Roper SD (2011a) Acid stimulation (sour taste) elicits GABA and serotonin release from mouse taste cells. PLoS One 6:e25471. CrossRef Medline

Huang YA, Stone LM, Pereira E, Yang R, Kinnamon JC, Dvoryanchikov G, Chaudhari N, Finger TE, Kinnamon SC, Roper SD (2011b) Knocking out $\mathrm{P} 2 \mathrm{X}$ receptors reduces transmitter secretion in taste buds. J Neurosci 31:13654-13661. CrossRef Medline

Huang YA, Grant J, Roper S (2012) Glutamate may be an efferent transmitter that elicits inhibition in mouse taste buds. PLoS One 7:e30662. CrossRef Medline

Huang YJ, Wu YH, Lu KS (2003) Immunoelectron microscopic studies on protein gene product 9.5 and calcitonin gene-related peptide in vallate taste cells and related nerves in the guinea pig. Microsc Res Tech 62:383-395. CrossRef Medline

Huang YJ, Maruyama Y, Lu KS, Pereira E, Plonsky I, Baur JE, Wu D, Roper SD (2005) Mouse taste buds use serotonin as a neurotransmitter. J Neurosci 25:843-847. CrossRef Medline

Huang YJ, Maruyama Y, Dvoryanchikov G, Pereira E, Chaudhari N, Roper SD (2007) The role of pannexin 1 hemichannels in ATP release and cell-cell communication in mouse taste buds. Proc Natl Acad Sci U S A 104:6436-6441. CrossRef Medline

Ishida Y, Ugawa S, Ueda T, Murakami S, Shimada S (2002) Vanilloid receptor subtype-1 (VR1) is specifically localized to taste papillae. Brain Res Mol Brain Res 107:17-22. CrossRef Medline

Ishida Y, Ugawa S, Ueda T, Yamada T, Shibata Y, Hondoh A, Inoue K, Yu Y, Shimada S (2009) P2X(2)- and P2X(3)-positive fibers in fungiform papillae originate from the chorda tympani but not the trigeminal nerve in rats and mice. J Comp Neurol 514:131-144. CrossRef Medline

Jaber L, Zhao FL, Kolli T, Herness S (2014) A physiologic role for serotonergic transmission in adult rat taste buds. PLoS One 9:e112152. CrossRef Medline

Juaneda C, Dumont Y, Quirion R (2000) The molecular pharmacology of CGRP and related peptide receptor subtypes. Trends Pharmacol Sci 21: 432-438. CrossRef Medline

Kaya N, Shen T, Lu SG, Zhao FL, Herness S (2004) A paracrine signaling role for serotonin in rat taste buds: expression and localization of serotonin receptor subtypes. Am J Physiol Regul Integr Comp Physiol 286: R649-R658. CrossRef Medline

Kelman L (2004) Osmophobia and taste abnormality in migraineurs: a tertiary care study. Headache 44:1019-1023. CrossRef Medline

Maggi CA, Meli A (1988) The sensory-efferent function of capsaicinsensitive sensory neurons. Gen Pharmacol 19:1-43. CrossRef Medline

Morara S, Wang LP, Filippov V, Dickerson IM, Grohovaz F, Provini L, Kettenmann H (2008) Calcitonin gene-related peptide (CGRP) triggers $\mathrm{Ca}^{2+}$ responses in cultured astrocytes and in Bergmann glial cells from cerebellar slices. Eur J Neurosci 28:2213-2220. CrossRef Medline

Murata Y, Yasuo T, Yoshida R, Obata K, Yanagawa Y, Margolskee RF, Ninomiya Y (2010) Action potential-enhanced ATP release from taste cells through hemichannels. J Neurophysiol 104:896-901. CrossRef Medline

Murayama N (1988) Interaction among different sensory units within a single fungiform papilla in the frog tongue. J Gen Physiol 91:685-701. CrossRef Medline

Nagai T, Kim DJ, Delay RJ, Roper SD (1996) Neuromodulation of transduction and signal processing in the end organs of taste. Chem Senses 21: 353-365. CrossRef Medline

Nagy JI, Goedert M, Hunt SP, Bond A (1982) The nature of the substance P-containing nerve fibres in taste papillae of the rat tongue. Neuroscience 7:3137-3151. CrossRef Medline

Nishimoto T, Akai M, Inagaki S, Shiosaka S, Shimizu Y, Yamamoto K, Senba E, Sakanaka M, Takatsuki K, Hara Y, Takagi H, Matsuzaki T, Kawai Y, Tohyama M (1982) On the distribution and origins of substance $P$ in the papillae of the rat tongue: an experimental and immunohistochemical study. J Comp Neurol 207:85-92. CrossRef Medline

Oka Y, Butnaru M, von Buchholtz L, Ryba NJ, Zuker CS (2013) High salt recruits aversive taste pathways. Nature 494:472-475. CrossRef Medline 
Pokabla MJ, Dickerson IM, Papka RE (2002) Calcitonin gene-related peptide-receptor component protein expression in the uterine cervix, lumbosacral spinal cord, and dorsal root ganglia. Peptides 23:507-514. CrossRef Medline

Prado MA, Evans-Bain B, Oliver KR, Dickerson IM (2001) The role of the CGRP-receptor component protein (RCP) in adrenomedullin receptor signal transduction. Peptides 22:1773-1781. CrossRef Medline

Reich A, Orda A, Wiśnicka B, Szepietowski JC (2007) Plasma concentration of selected neuropeptides in patients suffering from psoriasis. Exp Dermatol 16:421-428. CrossRef Medline

Rettinger J, Schmalzing G (2004) Desensitization masks nanomolar potency of ATP for the P2X1 receptor. J Biol Chem 279:6426-6433. CrossRef Medline

Riddle DR, Hughes SE, Belczynski CR, DeSibour CL, Oakley B (1990) Inhibitory interactions among rodent taste axons. Brain Res 533:113-124. CrossRef Medline

Romanov RA, Rogachevskaja OA, Bystrova MF, Jiang P, Margolskee RF, Kolesnikov SS (2007) Afferent neurotransmission mediated by hemichannels in mammalian taste cells. EMBO J 26:657-667. CrossRef Medline

Roper SD (1989) The cell biology of vertebrate taste receptors. Annu Rev Neurosci 12:329-353. CrossRef Medline

Roper SD (2014) TRPs in taste and chemesthesis. Handb Exp Pharmacol 223:827-871. CrossRef Medline

Rosenblatt MI, Dahl GP, Dickerson IM (2000) Characterization and localization of the rabbit ocular calcitonin gene-related peptide (CGRP)receptor component protein (RCP). Invest Ophthalmol Vis Sci 41: 1159-1167. Medline

Sardi C, Zambusi L, Finardi A, Ruffini F, Tolun AA, Dickerson IM, Righi M, Zacchetti D, Grohovaz F, Provini L, Furlan R, Morara S (2014) Involvement of calcitonin gene-related peptide and receptor component protein in experimental autoimmune encephalomyelitis. J Neuroimmunol 271: 18-29. CrossRef Medline

Silverman JD, Kruger L (1989) Calcitonin-gene-related-peptide-immunoreactive innervation of the rat head with emphasis on specialized sensory structures. J Comp Neurol 280:303-330. CrossRef Medline

Silverman JD, Kruger L (1990) Analysis of taste bud innervation based on glycoconjugate and peptide neuronal markers. J Comp Neurol 292: 575-584. CrossRef Medline

Simon SA, Liu L, Erickson RP (2003) Neuropeptides modulate rat chorda tympani responses. Am J Physiol Regul Integr Comp Physiol 284: R1494-R1505. CrossRef Medline

Taruno A, Vingtdeux V, Ohmoto M, Ma Z, Dvoryanchikov G, Li A, Adrien L, Zhao H, Leung S, Abernethy M, Koppel J, Davies P, Civan MM, Chaudhari N, Matsumoto I, Hellekant G, Tordoff MG, Marambaud P, Foskett JK (2013) CALHM1 ion channel mediates purinergic neurotransmission of sweet, bitter and umami tastes. Nature 495:223-226. CrossRef Medline

Vandenbeuch A, Pillias AM, Faurion A (2004) Modulation of taste peripheral signal through interpapillar inhibition in hamsters. Neurosci Lett 358:137-141. CrossRef Medline

Vandenbeuch A, Tizzano M, Anderson CB, Stone LM, Goldberg D, Kinnamon SC (2010) Evidence for a role of glutamate as an efferent transmitter in taste buds. BMC Neurosci 11:77. CrossRef Medline

Vandenbeuch A, Anderson CB, Parnes J, Enjyoji K, Robson SC, Finger TE, Kinnamon SC (2013) Role of the ectonucleotidase NTPDase2 in taste bud function. Proc Natl Acad Sci U S A 110:14789-14794. CrossRef Medline

Vandenbeuch A, Larson ED, Anderson CB, Smith SA, Ford AP, Finger TE, Kinnamon SC (2015) Postsynaptic P2X3-containing receptors in gustatory nerve fibres mediate responses to all taste qualities in mice. J Physiol 593:1113-1125. CrossRef Medline

Vandewauw I, Owsianik G, Voets T (2013) Systematic and quantitative mRNA expression analysis of TRP channel genes at the single trigeminal and dorsal root ganglion level in mouse. BMC Neurosci 14:21. CrossRef Medline

Walker CS, Conner AC, Poyner DR, Hay DL (2010) Regulation of signal transduction by calcitonin gene-related peptide receptors. Trends Pharmacol Sci 31:476-483. CrossRef Medline

Wang Y, Erickson RP, Simon SA (1995) Modulation of rat chorda tympani nerve activity by lingual nerve stimulation. J Neurophysiol 73:1468-1483. Medline

Willis WD Jr (1999) Dorsal root potentials and dorsal root reflexes: a double-edged sword. Exp Brain Res 124:395-421. CrossRef Medline

Yamasaki H, Kubota Y, Takagi H, Tohyama M (1984) Immunoelectronmicroscopic study on the fine structure of substance-P-containing fibers in the taste buds of the rat. J Comp Neurol 227:380-392. CrossRef Medline 